\title{
Ergo-Economical Analysis of Different Paddy Transplanting Operations in Eastern India
}

\author{
S. Pradhan ${ }^{1}$ and S.K. Mohanty ${ }^{2}$ \\ ${ }^{I}$ M.Tech student, Department of Farm Machinery and Power, College of Agricultural Engineering \& \\ Technology, OUAT, Bhubaneswar-751003 \\ ${ }^{2}$ Associate professor, Department of Farm Machinery and Power, College of Agricultural Engineering \& \\ Technology, OUAT, Bhubaneswar-751003
}

\begin{abstract}
Transplanting of paddy is very tedious job mostly done by female workers during Kharif season and by 2020 there would be 50 percent women against 42 percent at present. Manual hand transplanting consumes a lot of energy and time and full of fatigue, but the poor socio-economic condition of the farmers does not allow them to adopt power operated transplanter. Transplanting operation by different research centres have been developed as 2 row, 3 row, 4 row paddy transplanter. Keeping this in view fifteen female subjects were selected in the age group 18-45years in the central farm of OUAT. The mean value of age, weight, height, $\mathrm{VO}_{2}$ max and Body surface area were found to be 31.1 years, $51.7 \mathrm{Kg}, 153 \mathrm{~cm}, 1.71 \mathrm{l} / \mathrm{min}$ and $1.52 \mathrm{~m}^{2}$. Physiological parameters like Heart rate, Oxygen consumption rate and Relative cost of workload were measured in different transplanting operations. The mean value of working heart rate was observed to be maximum 137.4 beats/min in 4 row paddy transplanter followed by 130.8 beats/min in 3 row transplanter and 127.7 beats/min in 2 row transplanter and 113.4 beats/min in local transplanting. The Oxygen consumption rate and Relative cost of workload were observed to be maximum $1.10 \mathrm{l} / \mathrm{min}$ and 64.3 percent in 4 row transplanter followed by 1.02 $\mathrm{l} / \mathrm{min}$ and 59.6 percent in 3 row transplanter followed by $0.9 \mathrm{l} / \mathrm{min}$ and 57.8 percent in 2 row transplanter and lowest in local practices,i.e. $0.5 \mathrm{l} / \mathrm{min}$ and 33.4 percent. The field capacity was observed to be maximum 0.016 ha/h in 4 row transplanting followed by 0.014, 0.011, 0.009 ha/h in 3 row, 2 row and local method of transplanting. The cost of operation was observed to be Rs.2237 per ha in 4 row, Rs.2346 per ha in 3 row, Rs. 2484 per ha in 2 row paddy transplanter and Rs.2550 per ha in local practice of transplanting. The 3 row paddy transplanter was observed to be the best among all manual operated paddy transplanters.
\end{abstract}

Key words: Transplanter, Working Heart Rate, Oxygen Consumption Rate, Rest pause, Relative cost of workload

\section{Introduction}

Farm women perform hard physical work in planting crops with care and maintenance, harvesting and processing ,marketing and bartering of product simultaneously(Samants,1995).Presently workers engaged in various agricultural activities in our country and it's around 242 million. By 2020, the ratio of agricultural workers to the total workers is expected to decline to 40 percent from 52 percent, though the total number would remain the same (Gite,2012). From these about 50 percent would be women against $42 \%$ at present. In paddy cultivation transplanting is very drudgerious operation in overall paddy cultivation processes and 22.3 percent of total time is spent in this operation. Generally it is found that the production increases 10-12 percent in transplanting from direct sowing. In India several attempts have been taken to mechanize this transplanting operation by introducing various transplanters and this research is under progress to improve the cost of production with less fatigue. In OUAT two row transplanter and three row transplanter have been developed for female workers. Therefore the study is conducted to compare the ergo-economical suitability of different transplanters (two row transplanter, three row transplanter, four row transplanter) with local hand transplanting procedure. The human physiology study is done to compare the comfortness of mechanical transplanters with local transplanting .Generally a female worker has $2 / 3^{\text {rd }}$ of energy of male worker(Satpathy and Mohanty,2005). The local transplanting requires frequent bending down and straighten up for transplanting process where as mechanical transplanter require energy for pulling the transplanter in puddled field.

\section{Material and Methods}

This study was done at OUAT central farm in the month July-August. For Physiological data at first the HRrest, $\mathrm{Vo}_{2}$ rest, BSA, BMI, weight, age of the workers were measured and the mean value was considered for ergonomic evaluation. The fifteen selected subjects are in the age 18-44 and their body weight varies from 45- $59 \mathrm{~kg}$. The transplanting operation was done for 10 A.M. to 1.30 P.M. and 3 P.M to 5 P.M. before going to field their HRrest, Body Mass Index, Body Surface Area, and Volume of oxygen uptake were measured at lab. The operation was done in continuous transplanting for 30 minutes and taking 10 minutes break .After 30 
minutes of continuous operation Blood Lactate Accumulation, HR work, Energy Expenditure, RCWL were measured.

\section{A. Selection of subject and field}

The selected fifteen subjects were in the age group of 18-45 years as at this age maximum strength can be utilised they cover the $5^{\text {th }}$ to $95^{\text {th }}$ physical characteristics of total female population. The test was conducted in OUAT central farm which is of sandy loam soil and the test was conducted at about $32-35^{\circ} \mathrm{c}$ temperature and 72-75 percent humidity. The details of physical parameters are placed in table 1 below.

Table 1: Physiological parameters of selected subjects $(\mathrm{N}=15)$

\begin{tabular}{|l|l|l|l|}
\hline Physical and Physiological Parameters & Range & Mean & Std. Deviation \\
\hline Age, Years & $15-45$ & 31.1 & 8.06 \\
\hline Weight, Kg & $45-59$ & 51.7 & 4.91 \\
\hline Height, cm & $142.1-163$ & 152.3 & 7.61 \\
\hline HR rest, beats/min & $65-76$ & 70.3 & 3.17 \\
\hline $\mathrm{HR}$ max, beats/min & $176-200$ & 188.2 & 7.27 \\
\hline $\mathrm{VO}_{2}$ rest, 1/min & $0.16-0.24$ & 0.19 & 0.02 \\
\hline $\mathrm{VO}_{2} \mathrm{max}, 1 / \mathrm{min}$ & $1.56-1.81$ & 1.71 & 0.08 \\
\hline $\mathrm{BSA}, \mathrm{m}^{2}$ & $1.37-1.69$ & 1.52 & 0.12 \\
\hline BMI, Kg/m & $20.5-23.25$ & 22.32 & 0.82 \\
\hline $\begin{array}{l}\text { Blood Lactate Accumulation } \\
\text { (Mm/l of blood) }\end{array}$ & $0.9-1.3$ & 1.2 & 0.08 \\
\hline
\end{tabular}

\section{B. Calibration of subjects}

The selected subjects are calibrated in laboratory before conducting the test. To know the maximum heart rate, maximum oxygen consumption, heart rate at rest the subjects were undergone treadmill test. The average value of fifteen subjects was taken as representing value for working duration. The heart rate was measured by Polar heart rate monitor and oxygen uptake was measured by Metamax-II. The Energy Expenditure was calculated by the formula

$\mathrm{EER}=\mathrm{VO}_{2}$ consumption $\times 23.96($ Varghese M.A.,1994)

The detail of specifications of 2 row, 3-row and 4 row transplanter are placed in Table-2.

Table-2: Specification of different transplanters

\begin{tabular}{|c|l|l|l|l|}
\hline $\begin{array}{l}\text { S1. } \\
\text { No. }\end{array}$ & Details & \multicolumn{3}{|c|}{ Specifications } \\
\hline 1 & Name & $\begin{array}{l}\text { OUAT 2- row } \\
\text { transplanter }\end{array}$ & $\begin{array}{l}\text { OUAT 3-row transplanter } \\
\text { Seedling } \\
\text { transplanter }\end{array}$ \\
\hline 2 & Type & $630 \times 600 \times 400$ & $\begin{array}{l}\text { Manual using mat type } \\
\text { seedling } \\
\text { seedling }\end{array}$ & $910 \times 565 \times 655$ \\
\hline 3 & Dimensions $(\mathrm{L} \times \mathrm{W} \times \mathrm{H})$ & 16 & $600 \times 600 \times 940$ & 24 \\
\hline 4 & Weight, $\mathrm{Kg}$ & 2 & 18 & 4 \\
\hline 5 & No. of rows & 24 & 3 & 24 \\
\hline 6 & Row spacing, cm & $3-4$ & 24 & $3-4$ \\
\hline 7 & Planting depth & $30-35$ & $3-4$ & $30-35$ \\
\hline 8 & No. of hills per square meter & $2-5$ & $30-35$ & $2-5$ \\
\hline 9 & No. of seedlings per hill & 0.008 & $2-5$ & 0.02 \\
\hline 10 & Field capacity(ha/h) & $108 \mathrm{~N}(11 \mathrm{kgf})$ & 0.01 & $183 \mathrm{~N}(18.6 \mathrm{kgf})$ \\
\hline 11 & Force Requirement & $50-60 \%$ & $145 \mathrm{~N}(14.8 \mathrm{kgf})$ & $50-60 \%$ \\
\hline 12 & Field efficiency & Rs.5500/- & $50-60 \%$ & Rs.9000/- \\
\hline 13 & Cost of transplanter & & & \\
\hline
\end{tabular}

\section{Result And Discussion}

\section{A. Physical and Physiological characteristics of female subjects:}

The mean heart rate of subjects at rest is found in the range 65 to 75 whereas the mean value was 70.28 and the corresponding oxygen consumption was $0.19 \mathrm{l} / \mathrm{min}$. The maximum oxygen consumption of female subjects were found to be $1.71 \mathrm{l} / \mathrm{min}$ and lies in the range $1.55-1.80$.The mean body mass index was found to be $22.3 \mathrm{~kg} / \mathrm{m}^{2}$ and body surface area was $1.52 \mathrm{~m}^{2}$ which shows that the workers were of normal health. 


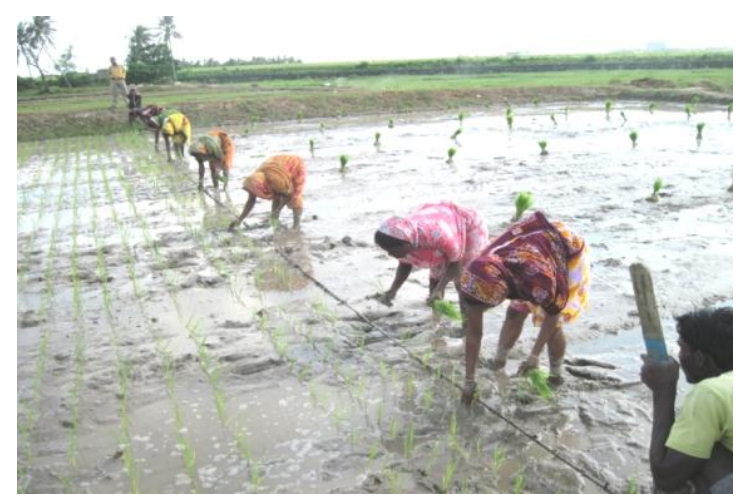

Fig 1: Manual line transplanting

B. Comparative Ergonomical Evaluation of different transplanter with manual transplanting:

The ergonomical parameters of the female subjects changed according to the type of transplanting procedure from rest value after 30 minutes of work. These values were given in the Table-3.

Table 3: Variation of Ergonomical parameters

\begin{tabular}{|l|l|l|l|l|}
\hline & $\begin{array}{l}\text { Local } \\
\text { Practices }\end{array}$ & $\begin{array}{l}\text { 2-row } \\
\text { transplanter }\end{array}$ & $\begin{array}{l}\text { 3-row } \\
\text { transplanter }\end{array}$ & $\begin{array}{l}\text { 4-row } \\
\text { transplanter }\end{array}$ \\
\hline $\mathrm{HR}_{\text {rest }}$ (beats/min) & 70.3 & 70.2 & 70.6 & 70.7 \\
\hline $\mathrm{HR}_{\text {work }}$ (beats/min) & 113.4 & 127.7 & 130.8 & 137.4 \\
\hline Work pulse (beats/min) & 43.0 & 64.6 & 58.2 & 67.0 \\
\hline $\mathrm{VO}_{2 \text { rest }}(1 / \mathrm{min})$ & 0.19 & 0.20 & 0.20 & 0.20 \\
\hline $\mathrm{VO}_{2 \text { work }}(1 / \mathrm{min})$ & 0.5 & 0.9 & 1.02 & 1.10 \\
\hline $\mathrm{EER}, \mathrm{kJ} / \mathrm{min}$ & 11.8 & 20.7 & 21.3 & 22.17 \\
\hline $\mathrm{RCWL}\left(\%\right.$ of $\mathrm{VO}_{2}$ max) & 33.4 & 57.8 & 59.6 & 64.3 \\
\hline Area coverage, ha/day & 0.03 & 0.065 & 0.08 & 0.10 \\
\hline Man days/ha & 17 & 16.6 & 11.3 & 8.5 \\
\hline Continuous operating Time,min & 56 & 32 & 28 & 17 \\
\hline
\end{tabular}

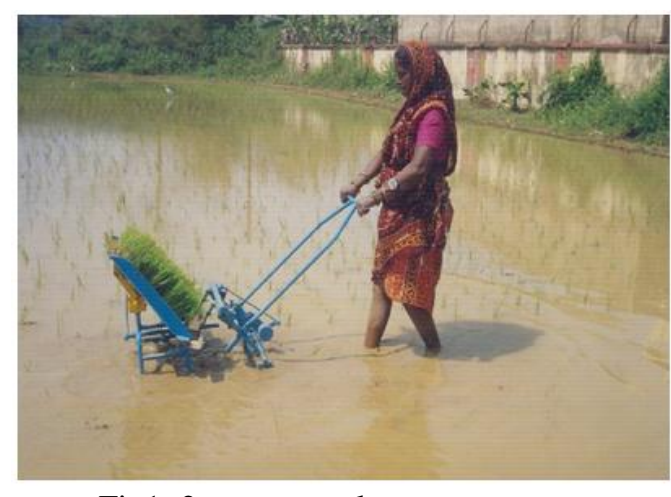

Fig1: 2-row transplanter

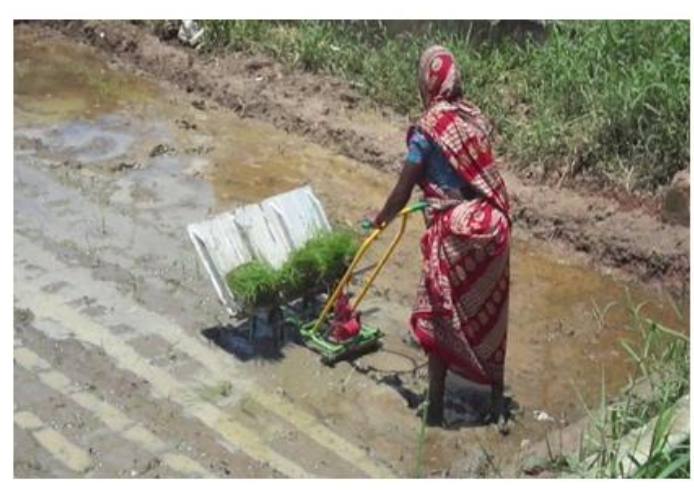

Fig2: 3 row transplanter

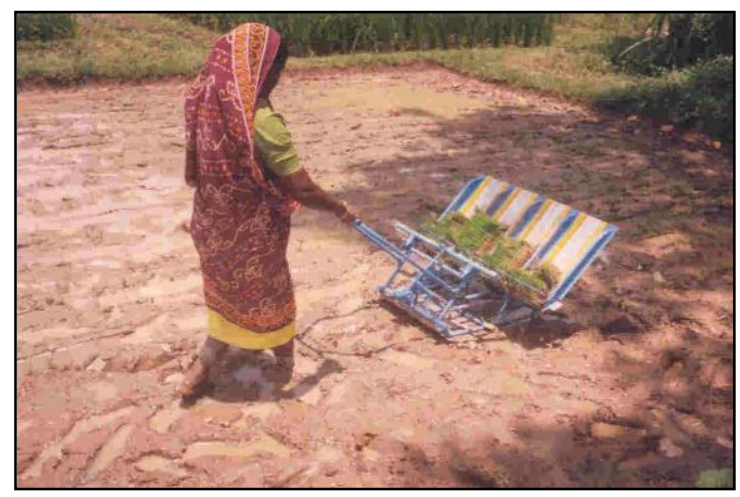

Fig3: 4 row transplanter 
Physiological response parameters changed due to work represents the level of fatigue or comfortness in a comparative way and according to these how much the workers can work efficiently. The table shows that the heart rate during work increases successively from the resting value $70.28 \mathrm{beats} / \mathrm{min}$ for local practices (113.4beats/min), 2-row transplanter(127.7 beats/min), 3-row transplanter (130beats/min) and for 4-row transplanter (137.4beats/min) .Likewise the volume of oxygen consumption during work increased to $0.51 / \mathrm{min}$ for local practice, $0.9 \mathrm{l} / \mathrm{min}$ for 2-row transplanter, 1.01/min for 3-row transplanter, $1.1 \mathrm{l} / \mathrm{min}$ for 4-row transplanter from the resting value. The work pulse in local practice is minimum and in three row trnsplanter it's lower from two row transplanter. The variation in these values is represented in the graph.

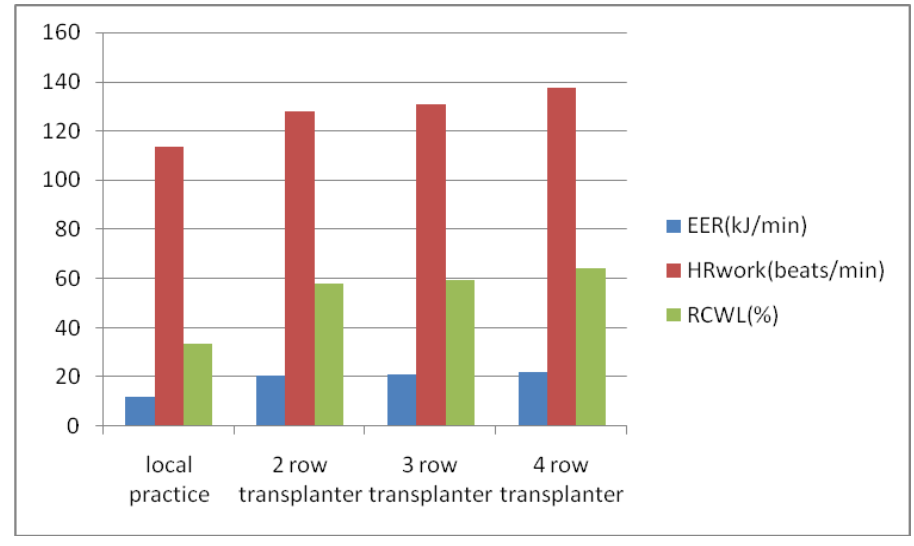

From this graph it is visible that the energy expenditure rate for four row transplanter is the highest followed by 3 row, 2 row and manual practice. So the working heart rate is optimum in case of 4 row transplanter than the others. This higher energy expenditure results in fatigue after a small period of time where as lesser working heart rate results more effective time of work.

\section{Economics of transplanting methods:}

The annual fixed cost and variable costs were calculated by depreciation method by taking the purchase cost, annual uses of transplanter and life of machine. The daily wage of workers was taken to be Rs. 150 with ten minutes break in every half an hour. The cost of operation per hectare were found to be Rs.2550 for local practice where as Rs.2484 for 2 row transplanter, Rs.2346 for 3 row transplanter and Rs.2237 for 4 row paddy transplanter. It was observed that while transplanting manually in bending posture the average area transplanted is $0.03 \mathrm{ha} /$ day. But maximum $0.10 \mathrm{ha} /$ day in case of 4 row paddy transplanter followed by 0.08 ha/day in 3 row and $0.065 \mathrm{ha} /$ day in case of 2 row paddy transplanter.

\section{Conclusion}

The ergo-economic analysis of different paddy transplanting methods revealed that the physiological response reduced in 2 row paddy transplanter from that of 3 row \& 4 row paddy transplanter. The HR work $, \triangle \mathrm{HR}, \mathrm{OCR}, \mathrm{RCWL}$ were reduced from 137.4 beats $/ \mathrm{min}$ to 127.7 beats $/ \mathrm{min}, 67$ beats $/ \mathrm{min}$ to 58.2 beats $/ \mathrm{min}, 1.10$ $1 / \mathrm{min}$ to $0.9 \mathrm{1} / \mathrm{min}, 64.3$ percent to 57.8 percent from 4 row transplanter to 2 row transplanter. More force in pulling the transplanter in forward direction by female worker was obtained which was $183 \mathrm{~N}$ (18.6 kgf) in 4 row and lowest $104 \mathrm{~N}$ (11 kgf) in 2 row paddy transplanter. The average transplanting area was recorded minimum 0.03 ha/day in manual method of transplanting \& $0.10 \mathrm{ha} /$ day in 4 row transplanter. The continuous working time was recorded 17 minutes in 4 row transplanter, 28 minutes in 3 row and 32 minutes in 2 row transplanter. The cost of operation per hectare was calculated to be maximum Rs.2550 in manual transplanter and Rs. 2237 in 4 row transplanter. Keeping all the physiological and economical parameters into consideration the 3 row paddy transplanter was found to be the best among all transplanting methods.

\section{Refernces}

[1] Singh G, Sharma T R. and Bockhop C W. 1985. Field performance evaluation of a manual rice transplanter. Journal of Agril. Engg. Research. Vol. 32, Issue 3, pp. 259-268.

[2] Goel A C. and Verma K S. 2000. Comparative study of directly seeding and transplanted rice. Indian J. Agril. Research, 34(3): 194196.

[3] Patra A K. and Nayak B C. 2001. Grain yield of rice under different spacings. Indian Jr. of Agronomy, 46(3): 449-452.

[4] Obulamma U and Reddy R. 2002. Effect of spacing and seedling number on growth and yield of hybrid rice. Journal of Research, ANGRAU, 30(1): 76-78.

[5] Khan A S. and Gunkel, W W. 1988. Design and development of a 6-row Korean transplanter, Agril. Mechanization in Asia, Africa and Latin America (AMA), 19(1): 27-34. 
[6] Syedul, Md., Baque M A. and Ahmed D B. 2000. Modification test and evaluation of manually operated transplanter for low land paddy. Agril. Mechanization in Asia, Africa and Latin America (AMA), 31(2): 33-37.

[7] Manjunatha M V., Masthana Reddy B G., Shashidhar S D. and Joshi V R. 2009. Studies on the performance of self-propelled rice transplanter and its effect on crop yield. Karnataka J. Agric. Sci., 22(2) :(385-387).

[8] Ved Prakash Chaudhary and Varshney, B P. 2003. Performance evaluation of self-propelled rice transplanter under different puddle field conditions and sedimentation periods. Agril. Mechanization in Asia, Africa and Latin America (AMA), 34: 23-33.

[9] Tripathi S K., Jena H K. and Panda P. K. 2004. Self-propelled rice transplanter for economizing labour, Indian Farming, 54: 23 - 25.

[10] Satapathy G C. and Mohanty S K. 2005. Collection and compilation of anthropometric and strength data of male and female agricultural workers of Odisha. Annual Report of AICRP on Ergonomics and Safety in Agriculture, 1-10. Orissa Univ. of Agriculture and Technology, Bhubaneswar, India.

[11] Karunanithi R. and Tajuddin A. 2003. Physiological response of agricultural workers in rice farming operation. J. Agril. Engng. (ISAE), 40(1): pp 33-40.

[12] Astrand P O. and Rodahl K. 1977. A Textbook of work physiology. New York: Mc. Graw Hill.

[13] Baqui A. and Latin R M. 1982. Human energy expenditure in manually operated rice transplanter. Agril. Mechanization in Asia, Africa and Latin America (AMA), 14(1): 1982, pp14-16.

[14] Singh S P. Gite L P., Agarwal N. and Majumdar J. 2007 .Women friendly Improved Farm Tools and Equipment. Technical Bulletin No CIAE/2007/128.

[15] Nag P K. 1981. Predicting maximum oxygen uptake of workers engaged in agricultural tasks. Human Ergology, 10, 25-33.

[16] Samants RK, 1995, Women in Agriculture: perspective, issues and experiences, MD publication Pvt. Ltd, New Delhi, PP-109.

[17] Gite LP, 2012, Research highlights of AICRP on Ergonomics and safety in Agriculture, Technical bulletin No.CIAE/2012/152Verghese M A, Saha P N, Bhatnagar A, Narayane G G 1994.An acceptable workload for Indian workers. Ergonomics, 22: 1059-1071. 